Title

\title{
Preparation and mechanical properties of machinable alumina/mica composites
}

Author's Name

\section{Seiichi TARUTA*, Ryuji FUJISAWA and Kunio KITAJIMA}

Author's Affiliation

Department of Chemistry and Materials Engineering, Faculty of Engineering, Shinshu University,

4-17-1, Wakasato, Nagano-shi, Nagano, 380-8553, Japan

*Corresponding Author

Seiichi TARUTA

Department of Chemistry and Materials Engineering, Faculty of Engineering, Shinshu University,

4-17-1, Wakasato, Nagano-shi, Nagano, 380-8553, Japan

TEL: +81-26-269-5416

FAX: +81-26-269-5424

E-mail: staruta@gipwc.shinshu-u.ac.jp 


\begin{abstract}
Using a mica-crystallizing glass powder in which a large amount of mica crystal was precipitated and a larger amount of $\mathrm{MgF}_{2}$ component was contained as the raw materials of mica, machinable alumina/mica composites were obtained at $1400{ }^{\circ} \mathrm{C}$. In the firing process, magnesia component in the mica crystals reacted with alumina to form spinel at $1150-1200{ }^{\circ} \mathrm{C}$. The reaction made the mica crystals melt. However, the mica crystals were precipitated again during the cooling. Because a larger amount of $\mathrm{MgF}_{2}$ component was contained in the mica-crystallizing glass powder, the nucleation of the mica crystals was caused during the cooling by the residual magnesium and fluorine in the liquid phase and succeedingly the mica crystals were precipitated. The precipitated mica crystals grew to anisotropicaly larger size than alumina grains, which lowered the bending strength and Vickers hardness and little heightened the fracture toughness.
\end{abstract}

\title{
Keywords;
}

Sintering, Composites, Mechanical properties, $\mathrm{Al}_{2} \mathrm{O}_{3}$, Mica 


\section{Introduction}

Alumina ceramics are well known typical ceramics and show a favorable combination of physical and chemical properties, e.g. high strength and hardness, high heat resistance, excellent chemical durability and low electrical resistance, so such alumina ceramics are applied in the various fields as engineering materials, electrical insulators, biomaterials and so on. However, the alumina ceramics are difficult to be machined by conventional metal tools due to their hardness and brittleness as well as many other ceramics. Therefore, the machining costs are very high, which limits the application fields. The improvement of the machinability is very effective in not only the reduction of the machining costs but also the fabrication of complex shape ceramics, precision machining and machining efficiency.

Machinable $\mathrm{Al}_{2} \mathrm{O}_{3} / \mathrm{h}-\mathrm{BN},{ }^{1} \mathrm{Al}_{2} \mathrm{O}_{3} / \mathrm{Ti}_{3} \mathrm{SiC}_{2}{ }^{2}$ and $\mathrm{Al}_{2} \mathrm{O}_{3} / \mathrm{LaPO}_{4}$ composites, ${ }^{3-5}$ which utilize the machinability of h-BN, the plate or layered shaped structure of $\mathrm{Ti}_{3} \mathrm{SiC}_{2}$ and the weak interface between oxide and phosphate, respectively, have been reported. They could be cut and drilled using conventional machining tools. On the other hand, mica glass-ceramics have been well known machinable ceramics since Beal developed a glass ceramic containing mica by controlling crystallization of the base glass in $1971 .{ }^{6,7}$ The excellent machinability originates in the cleavage and the interlocking microstructure of mica platelet crystals. ${ }^{6,7}$ Utilizing the machinability of mica, we succeeded in fabricating machinable cordierite/mica ${ }^{8}$ and spinel/mica ${ }^{9}$ composites. These composites could be prepared at low temperatures of 1100-1200 ${ }^{\circ} \mathrm{C}$ by the sintering of cordierite or spinel raw materials and mica-composition $\left(\mathrm{KMg}_{3} \mathrm{AlSi}_{3} \mathrm{O}_{10} \mathrm{~F}_{2}\right)$ glass powder mixtures and the crystallization of mica from the powder mixtures. While the machinable composites containing h-BN ${ }^{1,5,10-12}$ and $\mathrm{Ti}_{3} \mathrm{SiC}_{2}{ }^{2}$ are fabricated by hot pressing and spark plasma sintering, our machinable composites containing mica ${ }^{8,9}$ can be fabricated without the special sintering apparatuses. Moreover, comparing with machinable composite containing phosphates, ${ }^{3-5,13}$ our machinable composites containing mica ${ }^{8,9}$ have a possibility of low-temperature sintering due to sintering through the liquid phase formed by melting of the additive glass. Thus, the fabrication at low temperatures using conventional apparatuses is the merit of our machinable composites. However, alumina/mica composites had been never prepared by the sintering of alumina and mica-composition glass powder mixtures. Because the mica-composition glass powder reacted with alumina to form spinel, mica was not crystallized. ${ }^{14}$

In this study, our aim was to fabricate machinable alumina/mica composites at low temperatures. So not only the mica-composition glass powder but also the mica-crystallizing glass powder which contained a large amount of mica crystals and an excess of $\mathrm{MgF}_{2}$ component over the mica-composition glass powder was used as the raw materials of mica. 
Both or either of these powders were mixed with alumina powder and sintered. In consequence, machinable alumina/mica composites were obtained at $1400{ }^{\circ} \mathrm{C}$. In this paper, the sintering behavior of the powder mixtures and the mechanical properties of the obtained composites are reported.

\section{Experimental procedure}

The reagents of $\mathrm{K}_{2} \mathrm{CO}_{3}, \mathrm{MgO}, \mathrm{Al}_{2} \mathrm{O}_{3}, \mathrm{SiO}_{2}$ and $\mathrm{MgF}_{2}$ were mixed in the chemical composition corresponding stoichiometric fluorophlogopite $\left(\mathrm{KMg}_{3} \mathrm{AlSi}_{3} \mathrm{O}_{10} \mathrm{~F}_{2}\right)$ composition, calcined at $900{ }^{\circ} \mathrm{C}$, melted in a sealed platinum container at $1450{ }^{\circ} \mathrm{C}$ and then quenched. The obtained glass was pulverized by a ball milling for $48 \mathrm{~h}$. In this way, the mica-composition glass powder was prepared. The above-mentioned reagents were mixed in the chemical composition which was an excess of 10 mass $\% \mathrm{MgF}_{2}$ over the mica-composition glass powder, calcined, melted in a sealed platinum container at $1450{ }^{\circ} \mathrm{C}$ and then cooled in the furnace. Mica was crystallized in the product. The product was pulverized by a ball milling for $48 \mathrm{~h}$. In this way, the mica-crystallizing glass powder was obtained. Such mica-composition glass and mica-crystallizing glass powders were characterized using a field-emission type scanning electron microscopy (FE-SEM; S-4100, Hitachi, Japan), an X-ray diffractometry (XRD-6000, Shimadzu, Japan) and a differential thermal analyzer (DTA-40, Shimadzu, Japan). The SEM photographs, X-ray diffraction (XRD) patterns and differential thermal analysis (DTA) curves of the both powders are shown in Fig.1, Fig. 2 and Fig. 3, respectively. The SEM photographs indicate that most particles in both powders were less than $1 \mu \mathrm{m}$ and a few particles were $2-4 \mu \mathrm{m}$. It was obvious in the XRD patterns that the mica-composition glass powder did not contain any crystals while a large amount of mica crystal was precipitated and a small amount of glass remained in the mica-crystallizing glass powder. In the DTA curve of the mica-composition glass powder, two exothermic peaks appeared at $730{ }^{\circ} \mathrm{C}\left(\mathrm{Tc}_{1}\right)$ and $970{ }^{\circ} \mathrm{C}\left(\mathrm{Tc}_{2}\right)$. $\mathrm{The} \mathrm{Tc}_{1}$ was attributed to the nucleus formation which might be corresponding to the precipitation of chondorodite $\left(4 \mathrm{MgO}_{2} \cdot 2 \mathrm{SiO}_{2} \cdot \mathrm{MgF}_{2}\right)$ and/or norbergite $\left(2 \mathrm{MgO} \cdot \mathrm{SiO}_{2} \cdot \mathrm{MgF}_{2}\right),{ }^{6,7}$ and the $\mathrm{Tc}_{2}$ was to the crystallization of mica. And endothermic transformation started at about $1050{ }^{\circ} \mathrm{C}\left(\mathrm{Tm}_{1}\right)$, which was attributed to the melt of the residual glass. In the DTA curve of the mica-crystallizing glass powder, any exothermic peaks of the crystallization were not observed and the glass included in the mica-crystallizing glass powder started to melt at about $1000{ }^{\circ} \mathrm{C}\left(\mathrm{Tm}_{2}\right)$.

The alumina powder (TM-DAR, Taimei Chemicals, Japan) was mixed by a ball milling with the mica-composition glass powder and/or the mica-crystallizing glass powder. The particle size of the alumina powder was less than $0.1 \mu \mathrm{m}$, which was much smaller than the particle size of the mica-composition glass and mica-crystallizing glass powders. The weight 
ratios of alumina/mica-composition glass/mica-crystallizing glass were 80/20/0, 80/0/20, 80/10/10, and 60/20/20. These four specimens are denoted by G20, C20, G10C10 and G20C20, respectively, as shown in Table 1 . The powder mixtures were calcined at $600{ }^{\circ} \mathrm{C}$ for $1 \mathrm{~h}$, passed through a 100-mesh sieve, compacted by a cold isostatic pressing at $98 \mathrm{MPa}$ and fired in a sealed platinum container at $1200-1450{ }^{\circ} \mathrm{C}$ for $2 \mathrm{~h}$. Both heating and cooling rates of the firing were $5{ }^{\circ} \mathrm{C} / \mathrm{min}$.

Crystalline phases in the specimens were determined using the X-ray diffractometry. The bulk densities and the true densities were measured by Archimedes method and pycnometer method, respectively. The fracture surfaces of the sintered specimens were observed using the FE-SEM. The three point bending strength was measured using a universal strength testing machine (AUTOGRAPH AG-100KNG, Shimadzu, Japan). The crosshead speed for the bending test was $0.5 \mathrm{~mm} / \mathrm{min}$. The hardness and fracture toughness were measured using a Vickers diamond indenter (Model-AVK, Akashi Seisakusho, Japan). The Vickers diamond was indented on the polished surface of specimens at load of $98 \mathrm{~N}$ for $10 \mathrm{sec}$. The fracture toughness was determined by indentation microfracture method (IM method). For the measurement of these mechanical properties, five test pieces per specimen were used. The machinability was qualitatively evaluated using a bench-drilling machine (DP-200, Takagi, Japan). The drill with a diameter of $3 \mathrm{~mm}$, which was made of hard metal, was used and the rotational frequency was $620 \mathrm{rpm}$.

\section{Results and discussion}

\subsection{Phase change and sintering}

XRD patterns of the G20 and G10C10 specimens are shown in Fig. 4 and Fig. 5, respectively. In the G20 specimen, very small peaks of mica were observed at $1300{ }^{\circ} \mathrm{C}$ and 1350 ${ }^{\circ} \mathrm{C}$ while relatively large peaks of spinel appeared at $\geq 1250{ }^{\circ} \mathrm{C}$. On the other hand, in the G10C10 specimen, distinct peaks of mica appeared at $\geq 1300{ }^{\circ} \mathrm{C}$, and simultaneously the peaks of spinel were observed. Also, in the C20 and G20C20 specimens, mica and spinel were observed, of which XRD patterns are not shown in this paper. These XRD results indicate that the excess $\mathrm{MgF}_{2}$ component in the mica-crystallizing glass powder was very effective in the crystallization of mica.

Incidentally, melting point of mica (fluorophlogopite) is about $1340{ }^{\circ} \mathrm{C}$, so mica should melt at $\geq 1350{ }^{\circ} \mathrm{C}$. Then, in order to examine the phase changes during firing, after firing at holding temperatures, the specimens were quenched immediately. The XRD patterns of the G10C10 specimen fired at $1150{ }^{\circ} \mathrm{C}$ and $1200{ }^{\circ} \mathrm{C}$ for $2 \mathrm{~h}$ and then quenched are shown in Fig. 6. 
At $\leq 1150{ }^{\circ} \mathrm{C}$, mica was observed but spinel did not almost appear. On the contrary, spinel was observed at $\geq 1200{ }^{\circ} \mathrm{C}$ but mica was not even at $1200{ }^{\circ} \mathrm{C}$ which is lower than melting point of mica. The same results were observed in the $\mathrm{C} 20$ and G20C20 specimens. The XRD patterns of the mica-crystallizing glass powder and spinel/mica composite ${ }^{9}$ which were fired at $1200{ }^{\circ} \mathrm{C}$ for $2 \mathrm{~h}$ and then quenched are shown in Fig. 7. This figure indicates that when the mica-crystallizing glass powder was alone fired at $1200^{\circ} \mathrm{C}$ or when the mica-composition glass, alumina and magnesia powder mixtures were fired at $1200^{\circ} \mathrm{C}$, the mica crystals remained in the specimens even after quenching.

Above results mean that magnesia component in the mica crystals reacted with alumina to form spinel at $1150-1200^{\circ} \mathrm{C}$, the reaction made the mica crystals melt at $\geq 1200^{\circ} \mathrm{C}$ and the mica crystals were precipitated again during the cooling. And the excess of $\mathrm{MgF}_{2}$ component in the mica-crystallizing glass powder played an important role in the crystallization of mica during the cooling. That is, using the mica-crystallizing glass powder which contained an excess of $\mathrm{MgF}_{2}$ component over the stoichiometric composition of mica, after the melting of the mica crystals, the residual magnesium and fluorine in the liquid phase must form chondorodite and norbergite which are known as the nuclei for the crystallization of mica in the glass-ceramics ${ }^{6,7}$ during the cooling and succeedingly the mica crystals were precipitated. On the other hand, if almost magnesia component in the mica crystals and glassy phase react with alumina to form spinel, mica crystals are not precipitated again during the cooling. Figure 3 shows that mica was crystallized at $<1000{ }^{\circ} \mathrm{C}$ in the mica-composition glass powder. Therefore, if the mica-composition glass powder contains an excess of $\mathrm{MgF}_{2}$ component, a larger amount of mica crystal is precipitated even in the G20 specimen.

The bulk densities of each specimen fired and then cooled at $5{ }^{\circ} \mathrm{C} / \mathrm{min}$ and those of the $\mathrm{C} 20$ and G10C10 specimens fired and then quenched are shown in Fig. 8. It is known that the alumina powder used in this study is densified at low temperatures of $1200-1300{ }^{\circ} \mathrm{C}$ because the alumina powder has high purity of $>99.99 \%$ and very fine particle size of $<0.1 \mu \mathrm{m}$. The G20 specimen was densified at low temperatures of $1200-1300{ }^{\circ} \mathrm{C}$, too. The bulk density of the G20 specimen showed the maximum at $1250{ }^{\circ} \mathrm{C}$. The relative density was $97 \%$. The densification of the $\mathrm{C} 20, \mathrm{G} 10 \mathrm{C} 10$ and $\mathrm{G} 20 \mathrm{C} 20$ specimens was impeded by the addition of the mica-crystallizing glass composition. The densification of the G20C20 specimen was not almost progressed. The maximum bulk densities of the $\mathrm{C} 20$ and $\mathrm{G} 10 \mathrm{C} 10$ specimens were obtained at $1400{ }^{\circ} \mathrm{C}$. The relative densities were $94 \%$ and $95 \%$, respectively. In this way, dense alumina/mica composites were obtained at $1400^{\circ} \mathrm{C}$. The quenched specimens had larger bulk densities than the specimens cooled at $5{ }^{\circ} \mathrm{C} / \mathrm{min}$. The difference was large conspicuously for the $\mathrm{C} 20$ specimen fired at lower temperatures. At $1400{ }^{\circ} \mathrm{C}$, the bulk densities of the specimens cooled at $5{ }^{\circ} \mathrm{C} / \mathrm{min}$ were almost the same with those of the quenched specimens. The densification was progressed by the 
melting of the mica crystals during the heating but was deteriorated by the crystallization of mica during the cooling. A larger number of nuclei should be formed at the same time in the $\mathrm{C} 20$ specimen because the $\mathrm{C} 20$ specimen contained a larger amount of $\mathrm{MgF}_{2}$ component than the G10C10 specimen. Consequently, a larger number of mica crystals should be precipitated during the cooling, which resulted in the extreme deterioration of the densification of the C20 specimen fired especially at lower temperatures.

SEM photographs of the fractured surfaces of the sintered specimens are shown in Fig. 9. In all specimens in this Figure, isotropic grains with size of $\leq 5 \mu \mathrm{m}$, which were alumina or spinel, were observed. In the $\mathrm{G} 20$ specimen fired at $1250^{\circ} \mathrm{C}$, flake-like mica crystals were not observed. In the $\mathrm{C} 20$ and $\mathrm{G} 10 \mathrm{C} 10$ specimens fired at $1400^{\circ} \mathrm{C}$, flake-like mica crystals with size of $\leq 8 \mu \mathrm{m}$ were precipitated uniformly among isotropic grains and formed the interlocking microstructure. In the $\mathrm{G} 20 \mathrm{C} 20$ specimen fired at $1250{ }^{\circ} \mathrm{C}$, flake-like mica crystals grew to the size of more than $15 \mu \mathrm{m}$. In this way, using mica-crystallizing glass powder, the anisotropic mica crystals grew to larger size than alumina grains during the cooling. This remarkable anisotropic growth of mica crystals was the main factor in the extreme deterioration of the densification especially at lower firing temperatures. And it limited the relative density to the maximum 95\%. Consequently, the $\mathrm{C} 20$ and G10C10 specimens did not reach full density.

\subsection{Mechanical properties}

The photograph of drilling test for the $\mathrm{C} 20$ and $\mathrm{G} 10 \mathrm{C} 10$ specimens fired at $1400{ }^{\circ} \mathrm{C}$ is shown in Fig. 10. The drill penetrated into these specimens with the thickness of about $3 \mathrm{~mm}$. Glass-ceramics composed of greater than two-thirds mica by volume are normally machinable, regardless of the morphology of the mica crystals, and those containing as little as one-third by volume of mica may be machinable if the aspect ratio of the crystals is large enough to cause a high degree of interlocking of the crystals. ${ }^{6,7}$ However, the $\mathrm{C} 20$ and G10C10 specimens contain mica crystal of only about $26 \mathrm{vol} \%$ even if the mica-crystallizing glass and the mica-composition glass powders completely crystallize into mica. Practically, the content of the precipitated mica crystal must be lower than 26 vol\%. However, the interlocking microstructure of the flake-like mica crystals was observed throughout the $\mathrm{C} 20$ and $\mathrm{G} 10 \mathrm{C} 10$ specimens as shown in Fig. 9 though the degree of the interlocking of mica crystals might be low. Therefore, the $\mathrm{C} 20$ and G10C10 specimens could be machined with the drill made of hard metal but could not be sufficiently machined with conventional high-speed steel tools. In addition, the large chippings were observed in the bottom side of the specimens by the machining. While one factor of the generation of the chippings was the technical problem of drilling, the low degree of the interlocking microstructure of mica crystals might contribute to the generation of the large 
chippings.

The mechanical properties of each specimen are shown in Table 2. The bending strength of the machinable $\mathrm{C} 20$ and G10C10 specimens was lower than that of the G20 specimen. The degradation of bending strength resulted from the precipitation of the anisotropic mica crystals with larger size than alumina grains and the lower relative density. The precipitation of softer mica crystals lowered the Vickers hardness. Since the toughing effect, such as deflection and branching of cracks, was generated by the mica crystals, the fracture toughness was improved.

\section{Conclusions}

As raw materials of mica, not only the mica-composition glass powder but also the mica-crystallizing glass powder in which a large amount of mica crystal was precipitated and a larger amount of $\mathrm{MgF}_{2}$ component was contained were used. By adding the 10 mass\% mica-composition glass powder and the 10 mass\% mica-crystallizing glass powder to alumina powder or by adding the 20 mass $\%$ mica-crystallizing glass powder, dense machinable alumina/mica compositions were obtained at $1400{ }^{\circ} \mathrm{C}$. In the firing process, magnesia component in the mica crystals reacted with alumina to form spinel at $1150-1200{ }^{\circ} \mathrm{C}$, which caused the melting of the mica crystals. During the cooling, however, residual magnesium and fluorine in the liquid phase formed the nuclei for the crystallization of mica and succeedingly the mica crystals were precipitated again. If almost magnesia component in the mica crystals and glassy phase react with alumina to form spinel, mica crystals are not precipitated during the cooling. And if the mica-composition glass powder contains an excess of $\mathrm{MgF}_{2}$ component, a dense machinable alumina/mica composite is obtained even by the single addition of the glass powder. The densification was progressed by the melting of mica crystals, but the anisotropic mica crystals grew to larger size than alumina grains during the cooling, which deteriorated the densification.

The dense alumina/mica composites obtained at $1400{ }^{\circ} \mathrm{C}$ could be machined by the conventional hard metallic tool. The precipitation of anisotropic large mica crystals lowered the bending strength and Vickers hardness but little heightened the fracture toughness. The bending strength was $400-450 \mathrm{MPa}$, which were the same level as that of the conventional monolithic alumina ceramics while the fracture toughness was 3.7-3.9 $\mathrm{MPa} \cdot \mathrm{m}^{0.5}$, which were little higher than that of the conventional monolithic alumina ceramics. The Vickers hardness was 11-14 $\mathrm{GPa}$, which was the same level as that of zirconia ceramics. 


\section{References}

1. Li, Y., Qiao, G. \& Jin, Z., Machinable $\mathrm{Al}_{2} \mathrm{O}_{3} / \mathrm{BN}$ composite ceramics with strong mechanical properties. Mater. Res. Bull., 2002, 37, 1401-1409.

2. Luo, Y., Li, S., Pan, W., Chen, J., \& Wang, R., Machinable and mechanical properties of sintered $\mathrm{Al}_{2} \mathrm{O}_{3}-\mathrm{Ti}_{3} \mathrm{SiC}_{2}$ composites. J. Mater. Sci., 2004, 39, 3137-3140.

3. Davis, J. B., Marshall, D. B., Housley, R. M. \& Morgan, P. E. D., Machinable ceramics containing rare-earth phosphates. J. Am. Ceram. Soc., 1998, 81, 2169-2175.

4. Min, W., Miyahara, D., Yokoi, K., Yamaguchi, T., Daimon, K., Hikichi, Y., Matsubara, T. \& Ota, T. Thermal and mechanical properties of sintered $\mathrm{LaPO}_{4}-\mathrm{Al}_{2} \mathrm{O}_{3}$ composites. Mater. Res. Bull., 2001, 36, 936-945.

5. Wang, R., Pan, W., Chen, J., Fang, M., Jiang, M. \& Luo, Y., Graded machinable $\mathrm{Si}_{3} \mathrm{~N}_{4} / \mathrm{h}-\mathrm{BN}$ and $\mathrm{Al}_{2} \mathrm{O}_{3} / \mathrm{LaPO}_{4}$ ceramic composite. Mater. and Design, 2002, 23, 565-570.

6. Höland, W., \& Beall, G., Glass-Ceramic Technology, The American Ceramic Society, Westerville, Ohio, 2002, pp. 124-129.

7. Chyung, C. H., Beal, G. H. \& Grossman, D. G., Electron Microscopy and Structures, In Proceedings of Fifth International Materials Symposium, University of California, Berkeley, CA, 1971, pp. 1167-94.

8. Taruta, S. Hayashi, T., \& Kitajima, K., Preparation of machinable cordierite/mica composite by low-temperature sintering. J. Eur. Ceram. Soc., 2004, 24, 3149-3154.

9. Taruta, S. Shinkawa, H., Sakai, M., \& Kitajima, K., Preparation and mechanical properties of machinable spinel/mica composites. J. Ceram. Soc. Japan, 2005, 113, 185-187.

10. Wang, R., Pan, W., Jiang, M., Chen, J. \& Luo, Y., Investigation of the physical and mechanical properties of hot-pressed machinable $\mathrm{Si}_{3} \mathrm{~N}_{4} / \mathrm{h}-\mathrm{BN}$ composites and FGM. Mater. Sci. Eng., 2002, B90, 261-268.

11. Kusunose, T., Sekino, T., Choa, Y. H. \& Niihara, K., Fabrication and microstructure of silicon nitride/boron nitride nanocomposites. J. Am. Ceram. Soc., 2002, 85, 2678-2688.

12. Kusunose, T., Sekino, T., Choa, Y.-H. \& Niihara, K., Machinability of silicon nitride/boron nitride nanocomposites. J. Am. Ceram. Soc., 2002, 85, 2689-2695.

13. Min, W., Daimon, K., Matsubara, T. \& Hikichi, Y., Thermal and mechanical properties of sintered machinable $\mathrm{LaPO}_{4}-\mathrm{ZrO}_{2}$ composites. Mater. Res. Bull., 2002, 37, 1107-1115.

14. Suzuki, S. S., Taruta, S. \& Takusagawa, N., Sintering and microstructure of alumina/mica and spinel/mica composites. Korean J. Ceram., 1998, 4, 363-367. 


\section{Figure captions}

Fig. 1. SEM photographs of (a) the mica-composition glass powder and (b) the mica-crystallizing glass powder.

Fig. 2. XRD patterns of (a) the mica-composition glass powder and (b) the mica-crystallizing glass powder. $(\bullet)$ : mica, $(\diamond)$ : sellaite $\left(\mathrm{MgF}_{2}\right)$.

Fig. 3. DTA curves of (a) the mica-composition glass powder and (b) the mica-crystallizing glass powder.

Fig. 4. XRD patterns of (a) the green compact of the G20 specimen and the sintered G20

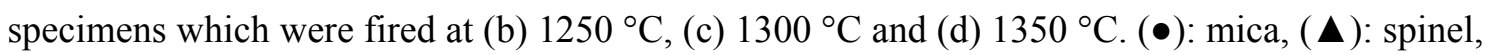
and (匹): alumina.

Fig. 5. XRD patterns of (a) the green compact of the $\mathrm{G} 10 \mathrm{C} 10$ specimen and the sintered G10C10 specimens which were fired at (b) $1300{ }^{\circ} \mathrm{C}$, (c) $1350{ }^{\circ} \mathrm{C}$ and (d) $1400{ }^{\circ} \mathrm{C}$. (•): mica, $(\boldsymbol{\Delta})$ : spinel, and (๘): alumina.

Fig. 6. XRD patterns of the G10C10 specimen fired at (a) $1150{ }^{\circ} \mathrm{C}$ and (b) $1200{ }^{\circ} \mathrm{C}$ for $2 \mathrm{~h}$ and then quenched. $(\bullet)$ : mica, $(\boldsymbol{\Delta})$ : spinel, and $(\boldsymbol{\bullet})$ : alumina.

Fig. 7. XRD patterns of (a) the mica-crystallizing glass powder fired at $1200{ }^{\circ} \mathrm{C}$ for $2 \mathrm{~h}$ and then quenched and (b) the spinel/mica composite fired at $1200{ }^{\circ} \mathrm{C}$ for $2 \mathrm{~h}$ and then quenched. $(\bullet)$ : mica and ( $\mathbf{\Delta})$ : spinel.

Fig. 8. Bulk densities of the $(\diamond) \mathrm{G} 20,(\bullet) \mathrm{C} 20,(\boldsymbol{\Delta}) \mathrm{G} 10 \mathrm{C} 10$ and (•) G20C20 specimens fired at $1200-1450{ }^{\circ} \mathrm{C}$ for $2 \mathrm{~h}$ and then cooled at $5{ }^{\circ} \mathrm{C} / \mathrm{min}$ and the (०) $\mathrm{C} 20$ and (A) $\mathrm{G} 10 \mathrm{C} 10$ specimens quenched after firing at $1250-1400^{\circ} \mathrm{C}$ for $2 \mathrm{~h}$.

Fig. 9. SEM photographs of the fracture surfaces of (a) the $\mathrm{G} 20$ specimen fired at $1250{ }^{\circ} \mathrm{C}$ for $2 \mathrm{~h}$, (b) the $\mathrm{C} 20$ specimen fired at $140{ }^{\circ} \mathrm{C}$ for $2 \mathrm{~h}$, (c) the $\mathrm{G} 10 \mathrm{C} 10$ specimen fired at $1400{ }^{\circ} \mathrm{C}$ for $2 \mathrm{~h}$ and (d) the G20C20 specimen fired at $1250^{\circ} \mathrm{C}$ for $2 \mathrm{~h}$.

Fig. 10. Photograph of drilling test for the (a) C20 and (b) G10C10 specimens fired at $1400^{\circ} \mathrm{C}$ for $2 \mathrm{~h}$. 
Table 1

The mixing rations of starting powders

\begin{tabular}{cccc}
\hline Specimen & Alumina powder & $\begin{array}{c}\text { Mica-composition } \\
\text { glass powder }\end{array}$ & $\begin{array}{c}\text { Mica-crystallizing } \\
\text { glass powder }\end{array}$ \\
\hline G20 & 80 & 20 & 0 \\
C20 & 80 & 0 & 20 \\
G10C10 & 80 & 10 & 10 \\
G20C20 & 60 & 20 & 20 \\
\hline
\end{tabular}

(Weight ratio) 
Table 2

Mechanical properties of each specimen

\begin{tabular}{ccccc}
\hline Specimen & $\begin{array}{l}\text { Firing Temp. / } \\
{ }^{\circ} \mathrm{C}\end{array}$ & $\begin{array}{l}\text { Bending strength } \\
/ \mathrm{MPa}\end{array}$ & $\begin{array}{l}\text { Vickers hardness } \\
/ \mathrm{GPa}\end{array}$ & $\begin{array}{l}\text { Fracture toughness / } \\
\mathrm{MPa} \square \mathrm{m}^{1 / 2}\end{array}$ \\
\hline $\mathrm{G} 20$ & 1250 & $646 \pm 20$ & $17.9 \pm 0.2$ & $2.9 \pm 0.2$ \\
$\mathrm{C} 20$ & 1400 & $405 \pm 13$ & $11.6 \pm 0.6$ & $3.9 \pm 0.1$ \\
$\mathrm{G} 10 \mathrm{C} 10$ & 1400 & $443 \pm 5$ & $13.8 \pm 0.2$ & $3.7 \pm 0.1$ \\
\hline
\end{tabular}



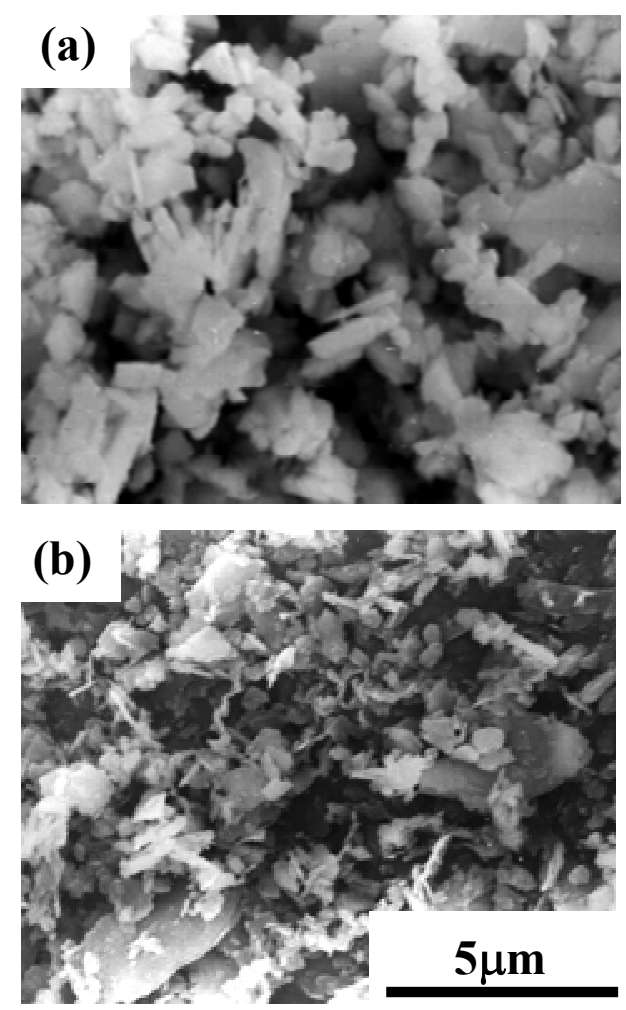

Fig. 1. SEM photographs of (a) the mica-composition glass powder and (b) the mica-crystallizing glass powder. 


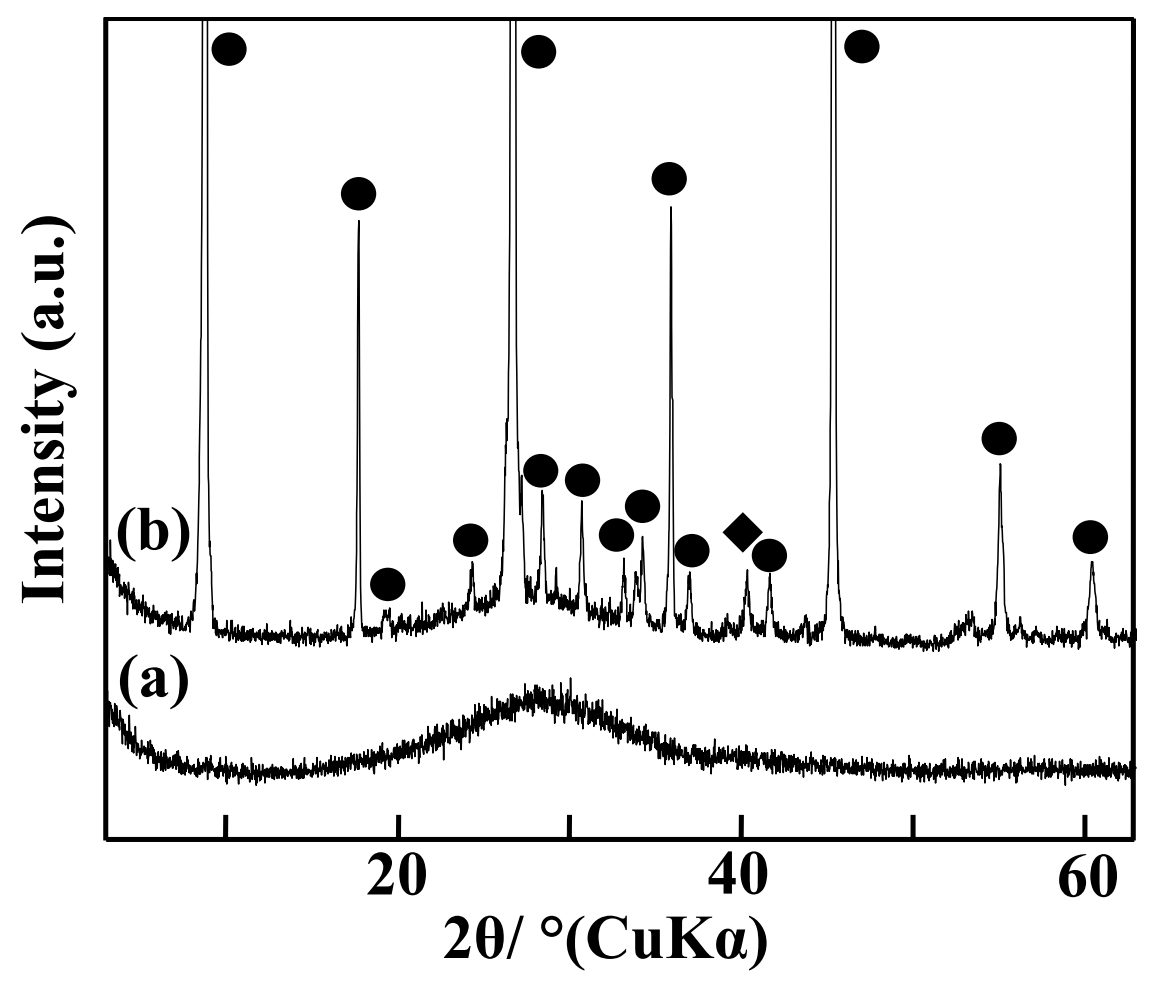

Fig. 2. XRD patterns of (a) the mica-composition glass powder and (b) the mica-crystallizing glass powder. (•): mica, $(\diamond)$ : sellaite $\left(\mathrm{MgF}_{2}\right)$. 


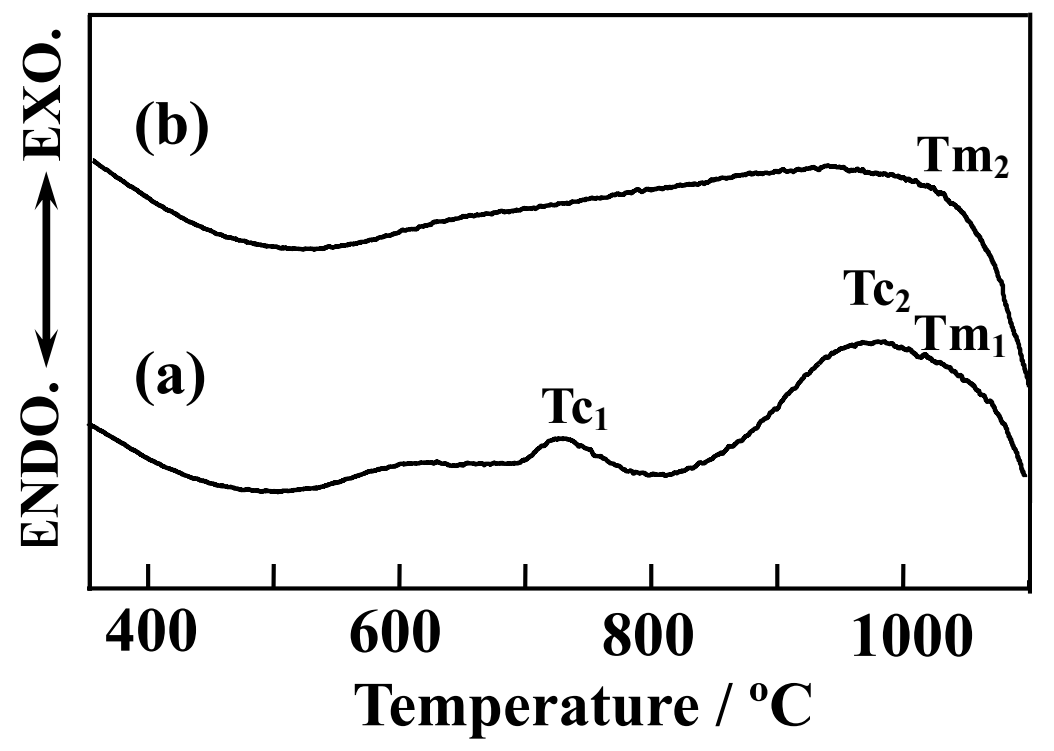

Fig. 3. DTA curves of (a) the mica-composition glass powder and (b) the mica-crystallizing glass powder. 


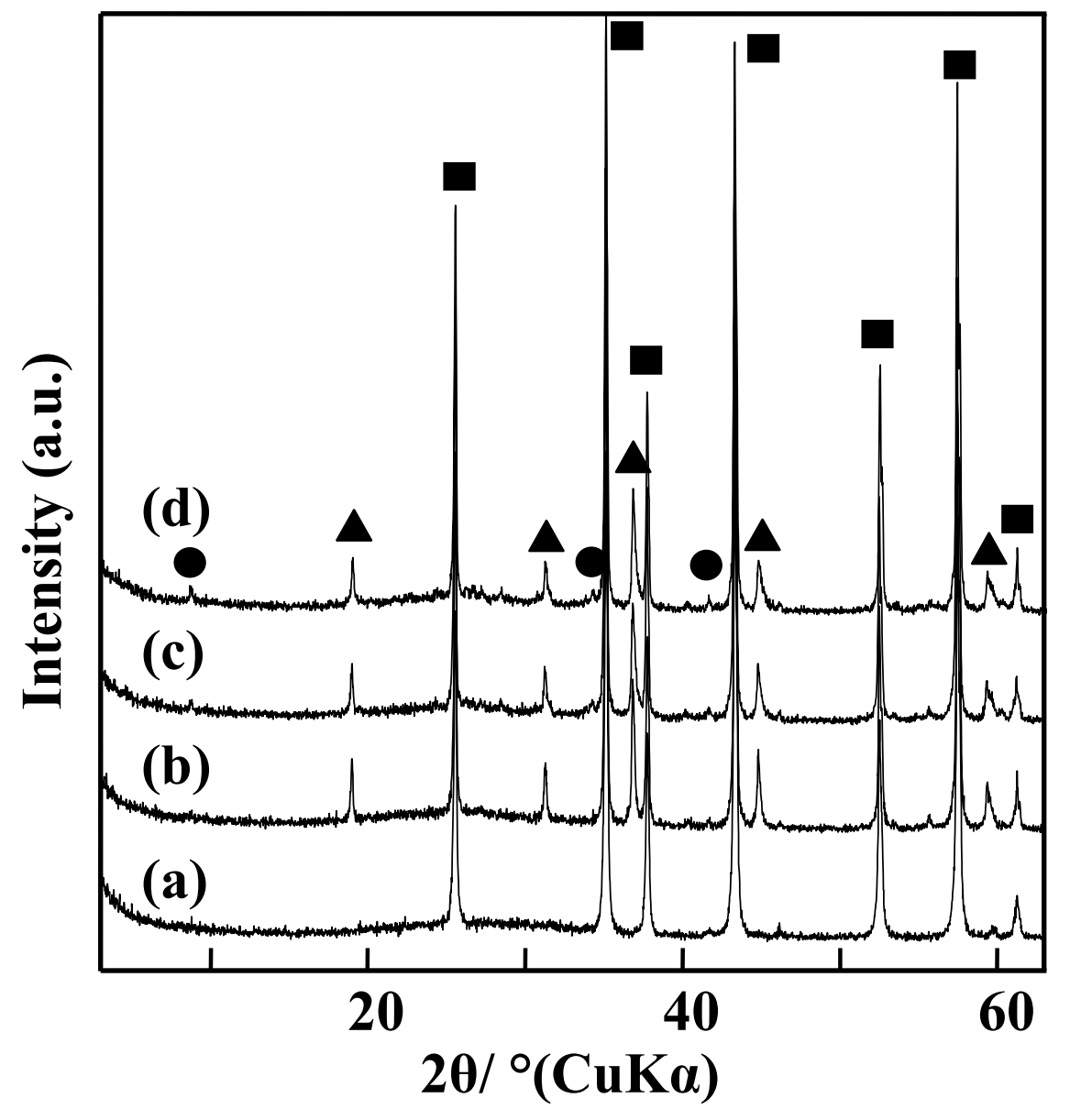

Fig. 4. XRD patterns of (a) the green compact of the G20 specimen and the sintered G20 specimens which were fired at (b) $1250{ }^{\circ} \mathrm{C}$, (c) $1300{ }^{\circ} \mathrm{C}$

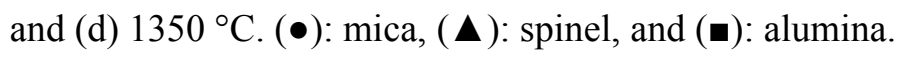




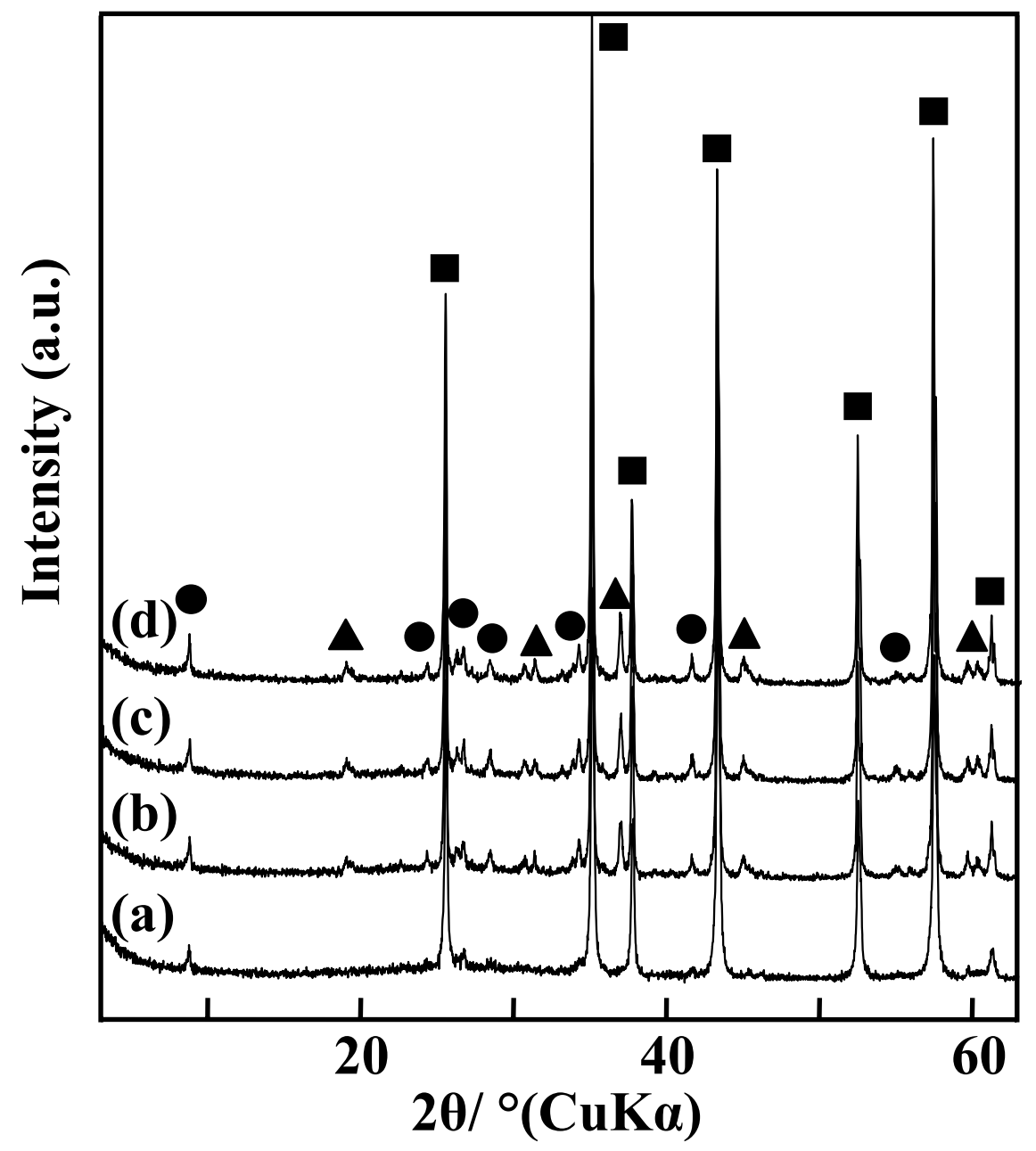

Fig. 5. XRD patterns of (a) the green compact of the G10C10 specimen and the sintered G10C10 specimens which were fired at (b) $1300{ }^{\circ} \mathrm{C}$, (c) $1350{ }^{\circ} \mathrm{C}$ and (d)

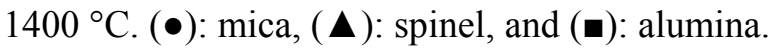




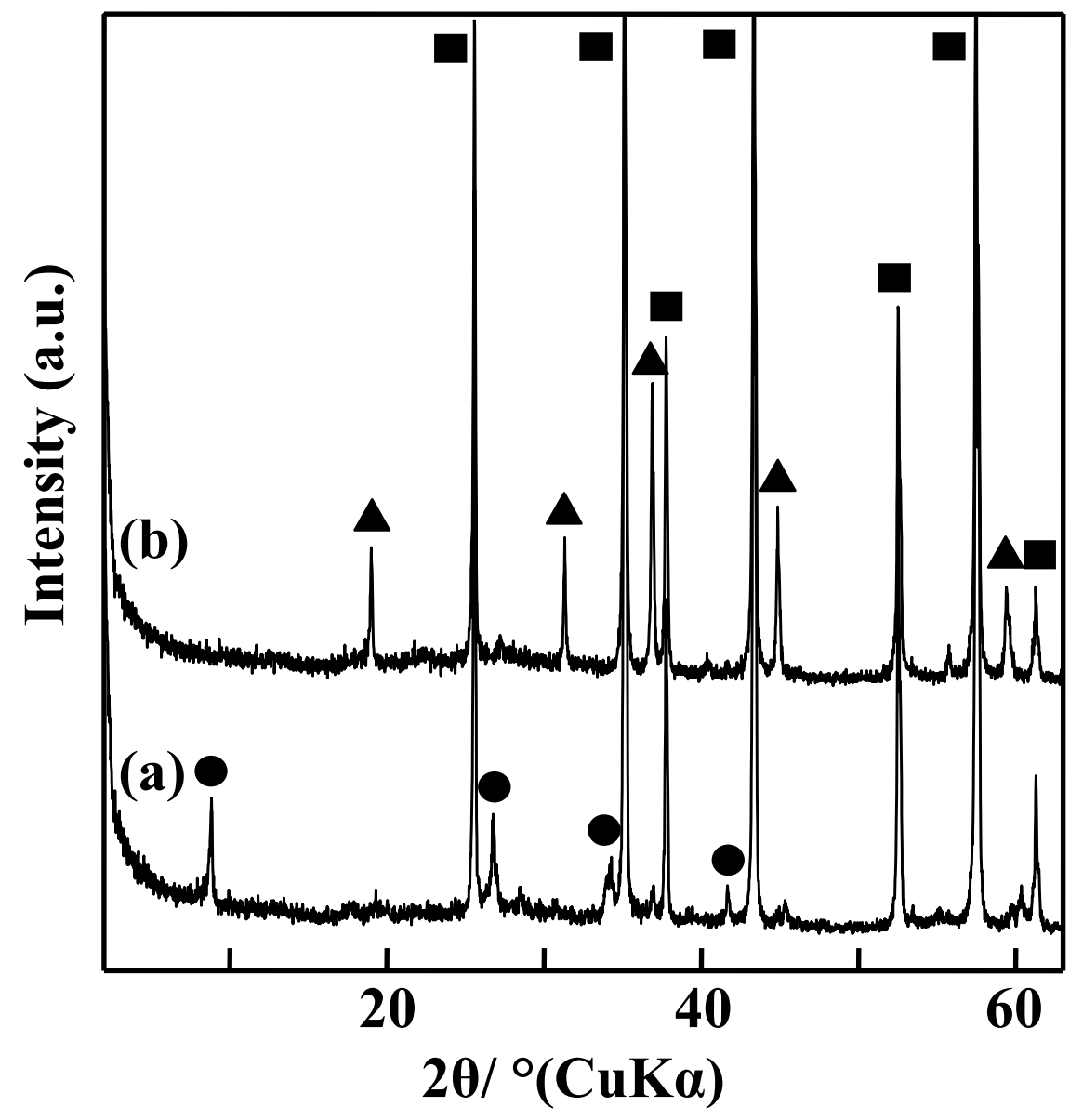

Fig. 6. XRD patterns of the $\mathrm{G} 10 \mathrm{C} 10$ specimen fired at (a) $1150{ }^{\circ} \mathrm{C}$ and (b)

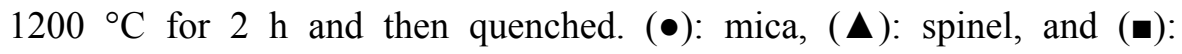
alumina. 


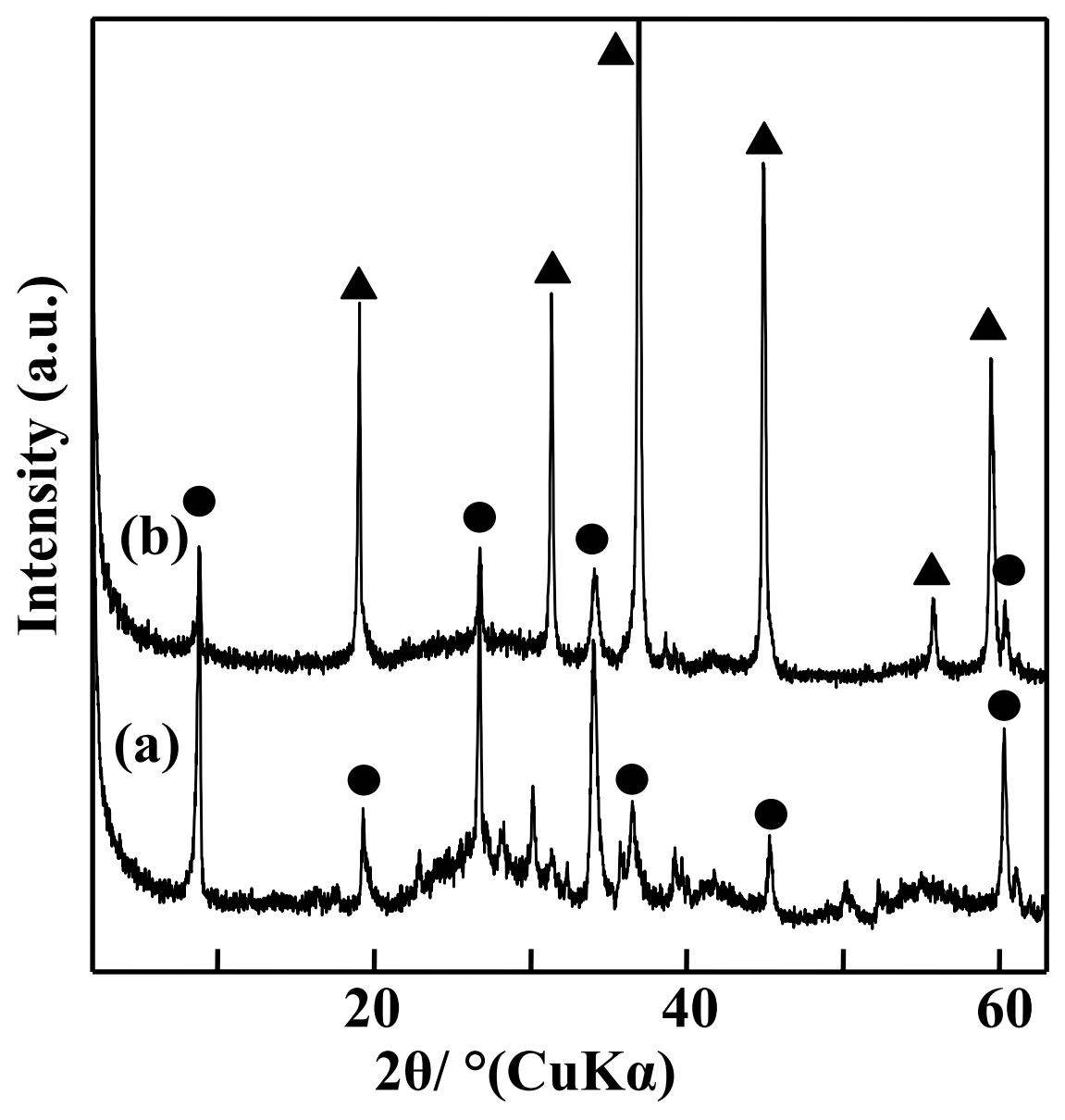

Fig. 7. XRD patterns of (a) the mica-crystallizing glass powder fired at $1200{ }^{\circ} \mathrm{C}$ for $2 \mathrm{~h}$ and then quenched and (b) the spinel/mica composite fired at $1200{ }^{\circ} \mathrm{C}$ for $2 \mathrm{~h}$ and then quenched. $(\bullet)$ : mica and $(\boldsymbol{\Delta})$ : spinel. 


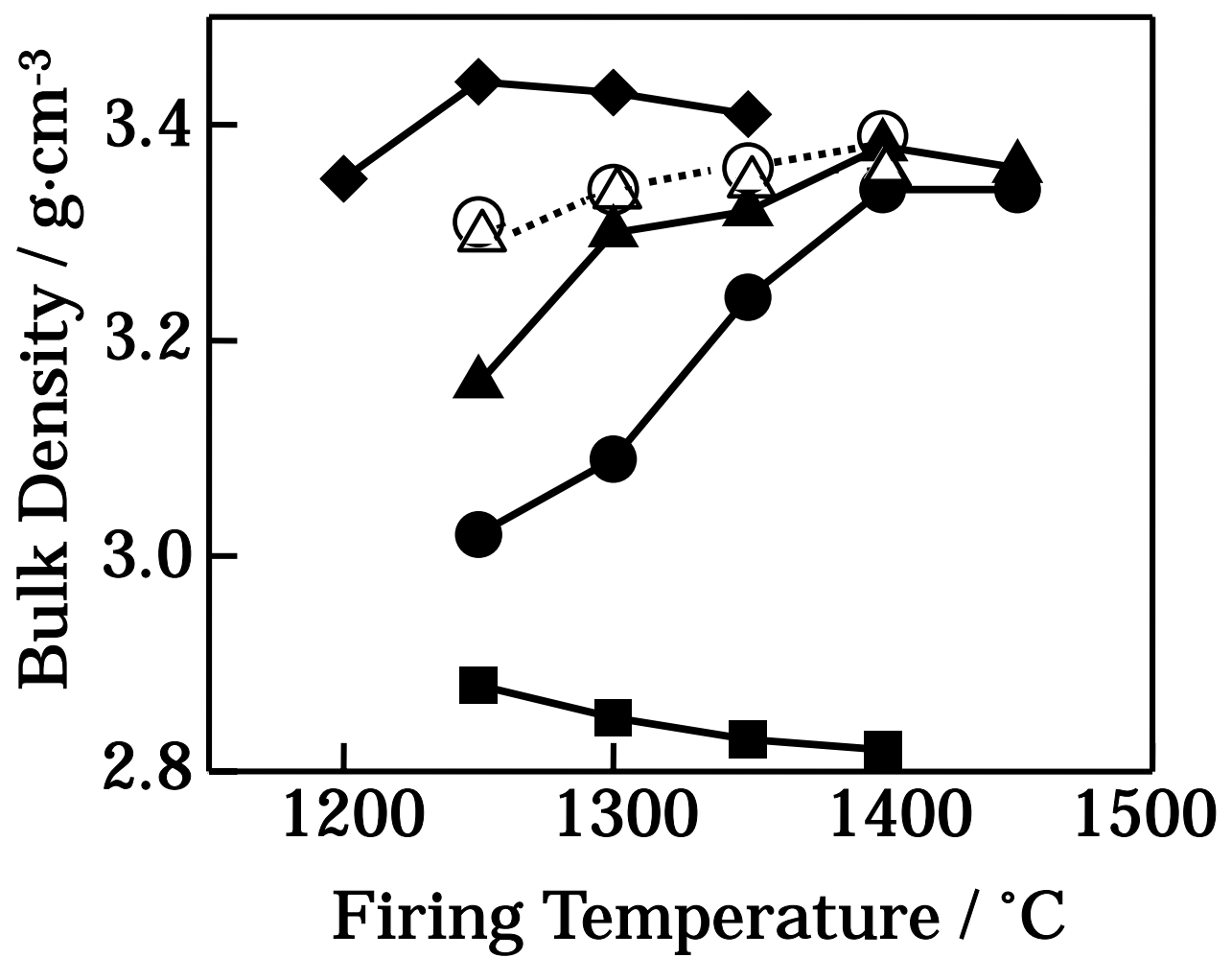

Fig. 8. Bulk densities of the $(\bullet) \mathrm{G} 20,(\bullet) \mathrm{C} 20,(\boldsymbol{\Delta}) \mathrm{G} 10 \mathrm{C} 10$ and (•) G20C20 specimens fired at $1200-1450{ }^{\circ} \mathrm{C}$ for $2 \mathrm{~h}$ and then cooled at $5{ }^{\circ} \mathrm{C} / \mathrm{min}$ and the (O) $\mathrm{C} 20$ and ( $\Delta$ ) G10C10 specimens quenched after firing at $1250-1400{ }^{\circ} \mathrm{C}$ for $2 \mathrm{~h}$. 

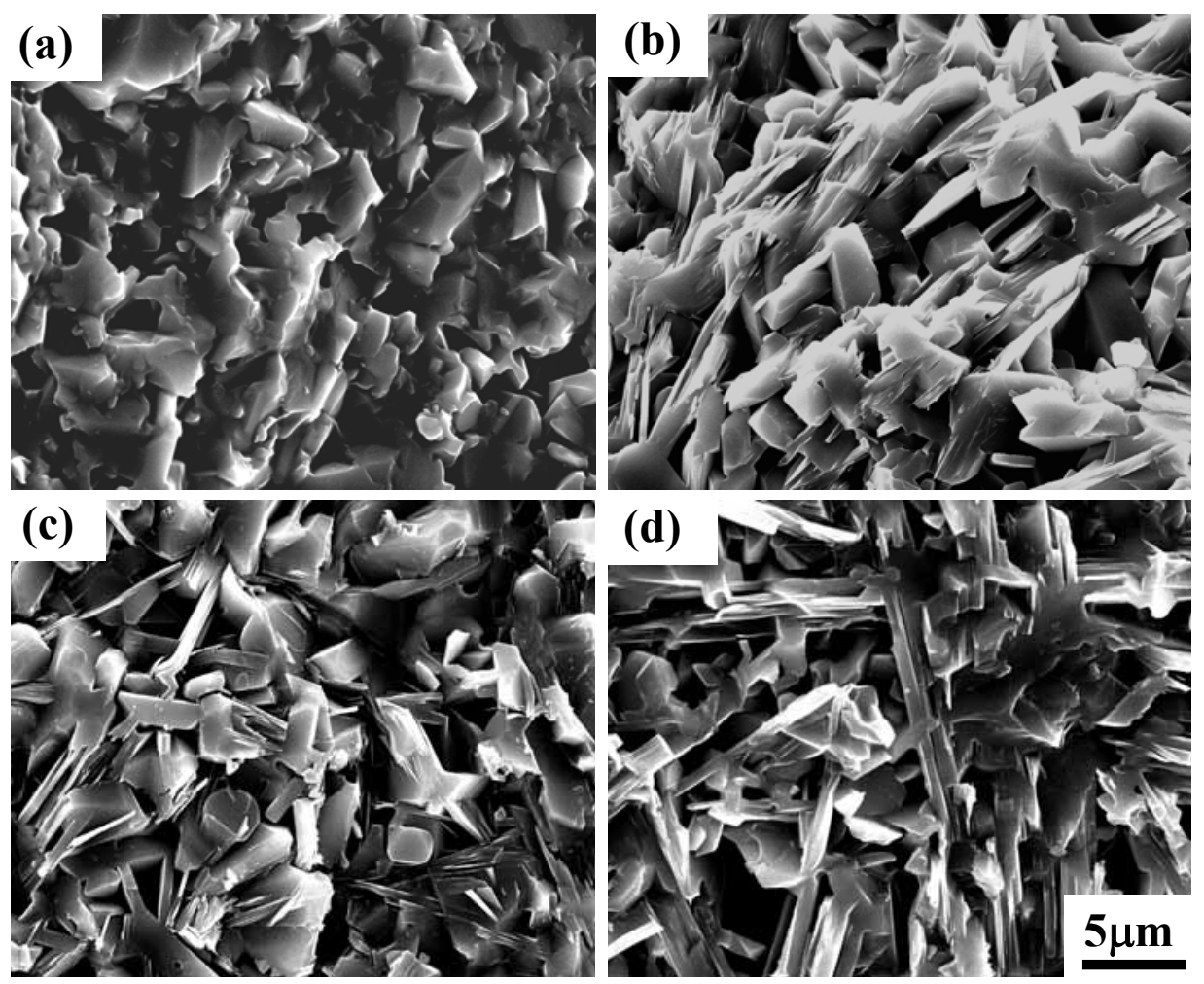

Fig. 9. SEM photographs of the fracture surfaces of (a) the G20 specimen fired at $1250{ }^{\circ} \mathrm{C}$ for $2 \mathrm{~h}$, (b) the $\mathrm{C} 20$ specimen fired at $1400^{\circ} \mathrm{C}$ for $2 \mathrm{~h},(\mathrm{c})$ the $\mathrm{G} 10 \mathrm{C} 10$ specimen fired at $1400{ }^{\circ} \mathrm{C}$ for $2 \mathrm{~h}$ and (d) the $\mathrm{G} 20 \mathrm{C} 20$ specimen fired at $1250^{\circ} \mathrm{C}$ for $2 \mathrm{~h}$. 


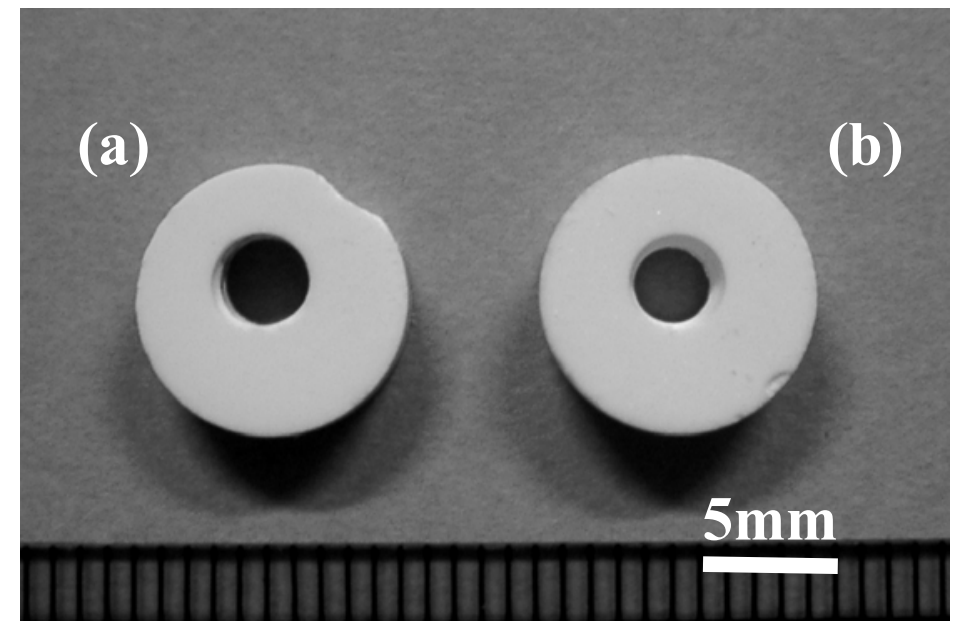

Fig. 10. Photograph of drilling test for the (a) $\mathrm{C} 20$ and (b) G10C10 specimens fired at $1400^{\circ} \mathrm{C}$ for $2 \mathrm{~h}$. 